\title{
Economics and the end of the nation-state
}

\author{
Brock H. Dickinson
}

\begin{abstract}
In the pre-millennial angst of the 1990s, an increasing number of journalists, political theorists and policy observers have begun to anticipate the decline of the Nation-State. It may be that much of this thinking is alarmist and naive, but at its heart exists some very real, very perplexing questions. Why did the Nation-State emerge as the dominant model of governance, and why did it succeed? What were its competitors, and why did they fail? And perhaps most importantly, how do the rapid economic and political changes sweeping our world today affect the viability of the Nation-State? This paper examines the complex mix of political, social and, above all, economic realities in place when the modern Nation-State was born, revealing patterns of societal change that mirror those at play in the emerging information economy. An analysis of its origins uncovers clues about its future, and about the ability of individual communities to benefit from the changes underway.
\end{abstract}

Keywords: Nation-State, governance, Peace of Westphalia, information economy

In the pre-millennial angst of the 1990s, an increasing number of journalists, political theorists and policy observers have begun to anticipate the decline of the Nation-State. While such predictions and prognostications have been with us for a century or two ${ }^{1}$, they have lately reached a crescendo. It may be that much of this thinking is alarmist and naive, but at its heart exists some very real, very perplexing questions. Why did the Nation-State emerge as the dominant model of governance, and why did it succeed? What were its competitors, and why did they fail? And perhaps most importantly, how do the rapid economic and political changes sweeping our world today affect the viability of the Nation-State?

At its most basic, the Nation-State is a social construct; it is a human invention. It exists because, for some reason, we believe that it has utility, that it is useful to us. As our needs change, that is, as the economy and the global political system are transformed around us, the utility of the Nation-State is also altered. As we enter the 21st Century, we must begin to ask ourselves whether such structures are still relevant, and whether they still offer the advantages that led to their creation.

It is widely held that the modern Nation-State was born with the signing of the Peace of

\footnotetext{
${ }^{1}$ Immanuel Kant, Karl Marx and Bertrand Russell all predicted the end of the Nation-State. Peter Drucker, "The Global Economy and the NationState," Foreign Affairs, January-February 1997, p. 159.
} 
Westphalia in 1648. Rather than being a product of a single treaty, however, the creation of the Nation-State was driven by a complex mix of the political, social and, above all, economic realities. Careful study of these factors reveals fascinating patterns of societal change that mirror those at play in the emerging Information Economy. With careful analysis of the historical models, and a stronger understanding of how the Information Economy is changing our modern world, it becomes possible to draw some conclusions about state structures in our own time, and the future of the Nation-State as a political unit. By studying this mix of history, politics and economics, it may not only be possible to better understand the origins of the Nation-State, but also to uncover clues about its future, and about the ability of individual communities to benefit from the changes underway.

\section{Chapter One: The beginnings of the nation-state}

Historians traditionally date the rise of the Nation-State to the Peace of Westphalia in 1648. Certainly, the signing of the Peace was a significant event, signalling an end to the Thirty Years War and the age-old struggle for political dominance between the Papal power of the Church and the secular might of the Holy Roman Empire. More importantly, however, the Peace of Westphalia also recognized the primacy of the newly emerging Nation-States, by recognizing that sovereign governments were the supreme authority within their own territorial boundaries. By extension, the Peace also proclaimed that each sovereign territory - each Nation-State - was on equal footing in the international arena. This concept of a 'club of Nation-States' transformed both Western thought and international relations, and a direct line can be drawn between the Peace of the Westphalia and the creation of such organizations as the League of Nations and the United Nations in the 20th Century. In large part, the concepts birthed at Westphalia continue to dominate the discourse of international relations, and continue to form the basis on which new Nation-States are recognized (or not recognized) by the international community.

In reality, of course, the origins of the Nation-State are found much earlier than 1648. Nor was the evolution of the Nation-State been a clean, clear linear process, with the Nation-State arising in a burst of logical inevitability. Evolution in nature is a messy, multifaceted process of trial and error, and the centuries-long fluctuation of governance and sovereignty was no different. Feudalism and the Divine Right of kings, the City-League and the Papal States, independent guilds and sovereign military orders all played themselves out on the international arena before the Nation-State rose to dominance.

With the sack of Rome by the Visigoths in 410, the Roman Empire fell into steep decline, plunging Europe into the Dark Ages. Political structures became temporary and transitory, with power accumulating in the hands of the prince, warlord or church leader best able to seize it. It was a period of political fragmentation and organizational anarchy. From this miasma, however, 
new political institutions began to arise, beginning with feudalism.

With the collapse of the Roman Empire's disparate successor states, such as the Carolingian Empire in what is now France, central authority capable of resisting external marauders ceased to exist. Magyar, Saracen and Viking depredations throughout Europe ushered in an era of increased insecurity, and drove home the need for local authorities to create some new, broader form of social organisation. ${ }^{2}$ This desire for greater social cohesion coincided with the introduction of heavy shock cavalry units amongst the Franks. As only the wealthy could afford horse and armour, this had the effect of concentrating power in the hands of a small military elite. While seeking stability, this new elite had a vested interest in avoiding the re-establishment of centralized authority. ${ }^{3}$

Against this backdrop, a traditional Germanic concept of quid pro quo political leadership took root, a system in which "leaders had a reciprocal relation with their followers." In essence, the emerging feudal system was one in which a group of individuals, known as vassals, would 'give' leadership to an individual, who would provide them with a variety of rights and privileges (often monetary) in return. As this notion developed, the feudal system grew increasingly complex, with each individual standing at the centre of a complex web of obligations and allegiances extending in multiple directions. It was quite possible for an individual to owe allegiance to several leaders at the same time, and to be offered allegiance by followers who had other, competing allegiances. So, for example, the Count of Luxemburg was a prince of the Holy Roman Empire, and thereby owed allegiance to the Emperor. At the same time, he received a pension from the French king, and therefore also owed allegiance to that king. "Consequently," suggests Spruyt, "a vassal might be caught in crosscutting obligations which are very difficult to comprehend within our understanding of "international' relations."

This diffuse system also meant that political control was distinct from territorial control. Indeed, the territoriality of power was unknown, for power transcended geography. As Spruyt argues:

As with all forms of political organization, feudal authorities occupied a geographical space. But such authority over territorial areas was neither exclusive nor discrete. Complex networks of rival jurisdictions overlaid territorial space. Church, lords, kings, emperor, and towns often exercised simultaneous claims to jurisdiction. Occupants of a particular territorial space were subject to a multiplicity of higher authorities.

\footnotetext{
${ }^{2}$ Hendrik Spruyt, The Sovereign State and its Competitors (Princeton, 1994), p. 37.

${ }^{3}$ Spruyt, p. 37.

${ }^{4}$ Spruyt, p. 37

${ }^{5}$ Spruyt, p. 39.
} 
By its very nature, the feudal system was only quasi-hierarchical; there were leaders and rulers, but they too were led and ruled, in a diffuse system of exchange and mutual obligation. This pattern changed very slowly, but over time, through a principle known as 'ligesse', some form of hierarchy began to emerge. Essentially, some types of homage, of feudal arrangement, began to be seen as superior to others, and as more important in the overall power structure.

The primary beneficiaries of this ligesse were monarchs, particularly in England and France. Over time, they were able to use the prestige of their bonds and feudal agreements to consolidate a degree of power and authority. Eventually, this increased power was sufficient to create the concept of the sovereign nation. As Post describes it:

Feudalism made the concept of the kingdom of the Franks so vague that in the 10th to 12th Centuries, except in remote theory, there was no state, no public law, and no idea of sovereignty. Yet the idea of the regnum Francorum, to become by 1200 the regnum Franciae, survived. In the 13th Century this idea, associated with the quasi-sacred character of the king, with the growing power of the French monarchy, and with the concept of the crown, culminated in the theory that the regnum was a sovereign, public corporate body... ${ }^{6}$

Similar processes were underway among the English, where it was possible to speak of a regnum Angliae. "From about 1150 on," suggests Post, "political and legal literature supported the theory as well as the fact of sovereignty.",

In essence, the concept of a sovereign English or French nation under a unified political structure had been born. However, this nation was one of common identity, not one of common territory. There was a King of the French, or a King of the English, but not, strictly speaking, a King of France or England. Sovereignty was divorced from territory.

This burgeoning perception of national sovereignty was accompanied by a period of rapid economic growth and expansion, beginning as early as the late 11th Century, but in full swing by the 14th Century. ${ }^{8}$ Effectively ending the Middle Ages, this economic renaissance was characterized by an altered perspective on geography, changing perceptions of time and timekeeping, changing notions of the nature of money and wealth, and the introduction of new economic principles and approaches. All of these factors expressed themselves in the introduction of new models of state governance structures, and ultimately in the birth of the Nation-State.

\footnotetext{
${ }^{6}$ Gaines Post, Sovereignty and its Limitations in the Middle Ages (1150-1350) (Moscow, 1970), p. 3.

${ }^{7}$ Post, p. 3.

${ }^{8}$ Spruyt, p. 63.
} 
By the dawn of the 12th Century, Europe was witnessing rapid and unprecedented economic expansion. Forests were cleared, and wastelands reclaimed. Agricultural production increased dramatically. Such activity, combined with the founding of new towns, contributed to a pattern of migration. While the feudal period had been characterized by sedentary, settled populations kept in place by feudal bonds between vassal and lord, the emerging post-feudal economy promoted mobility. Furthermore, increased economic activity soon lead to the return of longdistance trade, virtually non-existent since the collapse of the Roman Empire. ${ }^{9}$ Combined, these forces contributed to a perception of a larger world, of a sphere of interest that extended beyond the local and beyond the individual. Soon, business and commercial interests began to see a benefit to fixed spatial boundaries and uniform jurisdictions, where rules could be standardized and laws could be expected to follow established norms. These new notions of geography transformed the way people saw themselves, and their perceptions of the role of higher authority.

More profound in impact than this new sense of geography, however, was the new sense of time. Traditionally, time was within the domain of the Church, and was kept in order to hold the appropriate services at the appropriate hour. Aside from marking the passage of the seasons, the average person had little use for notions or demarcations of time outside of religious life. ${ }^{10}$ But again, with the expansion of commercial activity, a more formalized calculation of time was required. How long would production or delivery take? On what basis was interest to be calculated? Such questions inspired the emerging merchant class to take control of time, and build new tools for its measurement and management. The twenty-four hour day was adopted, and "mechanical clocks rather than church bells became the markers of time.",

The notion of money was also changing dramatically. Throughout the feudal period, financial transaction had been dominated by two models: gift exchange and donation. In the regions of Lucca and Florence, in modern Italy, 80 to 85 per cent of all commercial transactions before the year 1000 were carried out through gift exchange or donation. By 1150, 75 per cent of all commercial transactions were monetary in nature. ${ }^{12}$ Additionally, the Church's prohibition on the lending of money and the charging of interest ('usury') was crumbling. Where previously interest had been seen as a charge on time, which belonged to God, it was now increasingly seen as a reflection of the cost of money. Prototypical banking activities began to spring up, most notably with the Knights Templar. Founded around 1118, the Templars were a sovereign military-monastic order whose primary function was warfare in the Middle East, but their extensive travel, numerous fortresses and strongholds and immense wealth soon made them Europe's natural bankers. They invented numerous modern banking practices, including the ability to deposit funds in one location and withdraw them in another. As Simon suggests,

\footnotetext{
${ }^{9}$ Spruyt, p. 61.

${ }^{10}$ Spruyt, p. 74.

${ }^{11}$ Spruyt, p. 74.

${ }^{12}$ Spruyt, p. 75.
} 
"There have been some attempts to credit the Templars with the invention of the bank note - and of the check, the safe deposit, [and] the modern consulate..."13 Whatever the reality of these claims, it is clear the Templars "operated a system of national and international credit and finance."14 By 1307 the French king Philip the Fair was so heavily indebted to the Templars that he conspired with the Pope to destroy the Order and seize its wealth. Templar banking concepts had proved so successful, however, that their continuation was assured.

All of these changes fed into a radical transformation of the European economy. Economic power no longer lay in the hands of the political and military elite, but was increasingly migrating towards a new commercial class, with a vastly different set of interests and priorities. To evade feudal controls, these merchants moved out of the existing towns and fortified strongholds, and established large numbers of new towns and villages. As Spruyt suggests, "Many European towns that exist today can be traced to this period." 15

In this climate of rapid economic change and a changing political landscape, new power alliances began to emerge. The merchant class in particular began to seek out political entrepreneurs that could develop new governance institutions that would meet their needs. These new political alliances thus had a vested interest in fixed territorial borders, uniform financial and legal systems, military security, and the free movement of goods. Outcomes varied by economic region and geography, but three principal state structures emerged from this process. In modern France, the beginnings of the sovereign Nation-State as we now know it began to emerge. In modern Italy, a large number of highly independent City-States emerged. In modern Germany, nominally independent city actors formed themselves into City-Leagues, like the Hanseatic League, with some degree of centralized authority. Thus, between the end of the Middle Ages and the Peace of Westphalia, for a period of three or four hundred years, a number of state governance structures, created by economic pressures, were in direct competition for dominance.

Modern observers are, of course, familiar with the Nation-State, which has come to dominate the international political arena. While examples of the City-State are still to be found, both traditional (Andorra, San Marino) and modern (Singapore, pre-1997 Hong Kong), its influence in modern politics has been minimal. The City-League has vanished altogether, in part because the signatories of the Peace of Westphalia in 1648 deliberately prevented the Hanseatic League from taking part in the treaty. As Spruyt argues:

City-leagues were incompatible with sovereign territorial states because leagues, such as the Hansa, had no clear territorial boundaries. In their desire to extend their political control over their economic sphere of interaction, they would

\footnotetext{
${ }^{13}$ Edith Simon, The Piebald Standard: The Story of the Knights Templars (Aldershot, 1959), p. 148.

${ }^{14}$ Stephen Howarth, The Knights Templar (New York, 1982), p. 240.

${ }^{15}$ Spruyt, p. 62.
} 
inevitably encroach on territorial units. Second, because of the absence of sovereign hierarchy, they lacked a clear focal point through which to coordinate their behaviour. City-states were more compatible in that they did have specific territorial limits to their claims of authority. Hence, external sovereignty and juridical equivalence came easier to that logic of organization. ${ }^{16}$

Thus, by the Peace of Westphalia, Europe was arguably familiar with at least seven forms of governance structure. These can be plotted on a simple two-axis grid, with the horizontal axis representing the degree of internal sovereignty (from fragmented to consolidated), and the vertical axis representing the degree of territorial demarcation.

In the modern world, aside from a handful of City-States, the theocratic Vatican State, and a single Military-Monastic Order in the form of the Sovereign Military Order of the Knights of Malta, the Nation-State has come to epitomize the concept of sovereignty. Clearly, in the crucial period between the late Middle Ages and the Peace of Westphalia, something propelled the Nation-State to pre-eminence. Traditionally, historians have argued that Nation-States were better at warfare than other state structures, and that the success of the Nation-State model was largely due to martial prowess. ${ }^{17}$ But if the primary driver of state reorganization in the late Middle Ages was economic change, it seems likely that economic rather than military processes lead to the dominance of the Nation-State model.

The first economic advantage the Nation-State model produced was a general standardization within a particular territory. In late 10th Century England, there were more than fifty systems of weights and measures, and by "the Late Middle Ages this had increased to several hundred major measurements with 25,000 local variations. The situation in the rest of Europe was no better."18 The City-Leagues were unable to force standardization of measures upon their members, while City-States could only standardize within an extremely limited geographic space. As early as the 12th Century, however, the French king began to push standardization of weights and measures across the entire French state. Although this process would not be complete until Napoleon's introduction of the metric system, the ever-increasing standardization of weights and measures within some nation-states provided economic advantage. Similarly, the standardization of coinage and currency offered advantage to those within Nation-States. Again, the French succeeded to a large degree in standardizing coinage, while in modern Germany, "there were roughly 2,500 local and regional authorities, and although not all of these minted, the chaotic currency and money conditions continued to greatly hamper German commerce."19

\footnotetext{
${ }^{16}$ Spruyt, p. 200.

${ }^{17}$ Spruyt, pp. 155-58.

${ }^{18}$ Spruyt, p. 159.

${ }^{19}$ Spruyt, p. 162.
} 
Figure 1.1. State models in the late Middle Ages $^{20}$

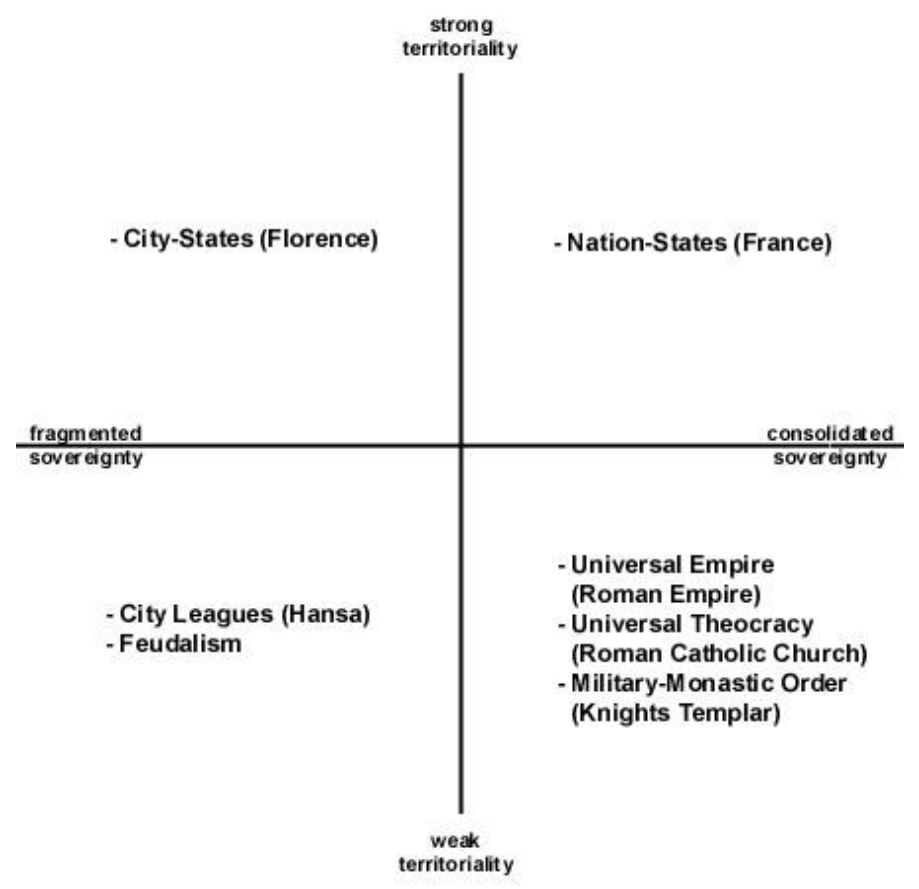

By the 16th Century, the Hanseatic League was attempting to standardize coinage among its members, most notably with currency minted in the town of Lubeck, but with little success. In the end, the standardization of the Nation-State approach won out, providing a clear economic impetus to organize along similar lines.

A second factor leading to the success of the Nation-State was its ability to restrict free-riding amongst its constituent parts. National taxation policies and perceptions of national interest could both be used to entice or force actors within a Nation-State to act in the Nation-State's best interests. Within the City-Leagues, this proved impossible. At the level of trade, each City was prepared to defect from its obligations if some advantage could be gained. Thus, while the Hanseatic League attempted a tight control over trade with the English, member towns like Hamburg, Elbing and Danzig opened their ports anyway. ${ }^{21}$ Indeed, emerging Nation-States like England and Denmark attempted to exploit this weakness with deliberate policy. Denmark, for example, keen on creating rifts within the Hanseatic League, exacted a toll for crossing the Danish Sound on ships flying flags of Prussian Hanseatic members, but exempted ships flying flags of Wend Hanseatic members. ${ }^{22}$ At a military level, too, the free-riding of some Hanseatic member cities proved problematic. Each member was required to provide troops for common defence, but the willingness to do so often depended on the political situation. As Spruyt decribes, "When the Wend towns fought the Danish in the 1420s, members of the Saxon group

\footnotetext{
${ }^{20}$ Adapted from Spruyt, p. 154.

${ }^{21}$ Spruyt, p. 164.

${ }^{22}$ Spruyt, p. 165.
} 
agreed to send help. However, they procrastinated in sending troops until Lubeck had effectively defeated the Danes by itself." 23 This willingness to accept the benefits of Hanseatic membership without meeting the obligations, came to characterize the City-League. And as the willingness to free-ride grew, it undermined the strength of the City-League vis-a-vis the Nation-State.

The third factor cementing the dominance of the Nation-State was its ability to act quickly and independently. By contrast, the disparate, multipartite nature of the City-Leagues prevented both speed and independent action. This was exacerbated by the fact that the 'interdependent' CityLeagues attempted to exert control wherever their economic interests lay, while the 'independent' Nation-States limited their activities within their own carefully defined territorial borders. As a result, Nation-States did not challenge each other's sovereignty (except in the case of territorial expansion), while the City-League was predicated upon exerting political authority inside the territorial boundaries of other states. In the period leading up to the Peace of Westphalia, this placed the City-League model in a position diametrically opposed to the era's major political and military powers.

The fourth factor contributing to the dominance of the Nation-State model was its hierarchical mode of organization. The emerging Nation-State model, best exemplified by England or France, was built around a centralized political structure with national decision-making authority, headed by a single figure (the king) with a (usually) clear line of succession. Such a structure lent itself to long-term political and economic stability. In contrast, the City-States and CityLeagues had highly unstable structures of governance. The City-Leagues, as we have seen, often lacked consistent and unified decision-making structures and approaches. The City-States, often without monarchical or hereditary authority, continually fell into civil war and the chaos of unclear succession, with "Town government that continually fluctuated between despotic, oligarchical and democratic regimes." ${ }^{24}$ Each of these competing factions claimed the right to exercise violence in pursuit of their interests, while in the Nation-State, the King was the sole provider of military force. In the end, this "fermentation within the... Cities and City-States left them, in the long run, in a disadvantageous position vis-a-vis their territorial counterparts in rationalizing their economies." 25

The final factor in the rise of the Nation-State was its ability to legitimize and empower other Nation-States. City-Leagues and City-States, in their pursuit of economic dominance, were often in direct competition with each other for economic control of disparate markets. Nation-States, on the other hand, were defined by their territorial boundaries, and could therefore recognize the legitimacy of Nation-States other than their own. In the end, this gave rise to a concept of

\footnotetext{
${ }^{23}$ Spruyt, p. 164

${ }^{24}$ Spruyt, p. 174

${ }^{25}$ Spruyt, p. 173.
} 
"juridical equivalence" 26 - a notion that in the international arena, Nation-States are somehow equal with each other, and can cooperate together. Because they were territorially-based, CityStates were also treated as if they had this juridical equivalence, although their other limitations made them poor cousins in the international arena. Such concessions were not extended to the City-Leagues. At the Peace of Westphalia in 1648, the Nation-States deliberately excluded the Hanseatic League. The Nation-States had concluded that:

City-Leagues were incompatible with sovereign, territorial states because leagues, such as the Hansa, had no clear territorial boundaries. In their desire to extend their political control over their economic sphere of interaction, they would inevitably encroach on territorial units. Second, because of the absence of sovereign hierarchy, they lacked a clear focal point through which to coordinate their behaviour. City-States were more compatible in that they did have specific territorial limits to their claims of authority. Hence, external sovereignty and juridical equivalence came easier to that logic of organization. ${ }^{27}$

Thus, by 1648 and the Peace of Westphalia, not only had Nation-States come to be the dominant form of political organization, they had also assumed the right to define who else would receive 'juridical equivalence'. In other words, the international system had become a private club whose members determined who else was suitable to join. Only the recognition of other NationStates could extend legitimacy to new governments and new nations. Consciously or otherwise, this process has continued to the present day, where the 'club of Nation-States' - most evident in the form of the United Nations - can proclaim that Somalia, without a government or cohesive organizing principle, is a Nation-State, while the Palestinian Authority, with a government, elections and a military, is not.

The Nation-State came to dominance, then, through a combination of economic and political factors. Nation-States established a system of mutual empowerment to legitimize each other, but more concretely they also were able to act independently, were organized along hierarchical models that allowed effective action, they decreased the ability of individuals and communities to free-ride, and they were channels for effective standardization of weights, measures and currencies. In a sense, the Nation-State as a model of governance provided its citizens with a greater degree of utility than its various competitors. This improved utility in turn afforded greater economic advantages, which prompted a widespread and longstanding adoption of the Nation-State model.

Utility is, of course, an economic concept, and it is possible to see the rise of the Nation-State in

\footnotetext{
${ }^{26}$ Spruyt, p. 68.

${ }^{27}$ Spruyt, p. 200
} 
strictly economic terms. As Lumsden describes it:

The gain from... incremental change is called the marginal benefit. The loss from the change is called the marginal cost. Any action or activity in which the marginal benefits exceed the marginal costs will, if undertaken, result in an increase of total utility... ${ }^{28}$

In mathematical terms, this concept can be expressed as follows:

(Marginal Benefits $)-($ Marginal Costs $)=($ Marginal Utility $)$

or

$\mathrm{MB}-\mathrm{MC}=\mathrm{MU}$

Following this approach, we can assume that if individuals follow profit-maximising behaviour (that is, if they seek the greatest marginal utility) they will ultimately adopt approaches and activities that increase marginal utility. In the Late Middle Ages, societies abandoned the feudal system for Nation-States, City-States and City-Leagues because these newer structures provided greater marginal utility. But given the different strengths and weaknesses of these new models, further rationalization was to take place. Unless Nation-States, City-States and City-Leagues all had identical marginal costs and identical marginal benefits, one of these systems was bound to become dominant because of its greater marginal utility. By 1648, the marginal utility of the Nation-State model was such that it had largely replaced its competitors.

This does not, of course, mean that the Nation-State is the most efficient, most effective type of governance available. It is not necessarily the case that Nation-States have a higher marginal utility than any other form of governance structure. It simply means that in the prevailing economic conditions of the Late Middle Ages, and measured against the performance of other existing governance structures, the Nation-State was the most productive model available. It is conceivable that, under other economic conditions, the City-State or the City-League, or for that matter feudalism, could have risen to the dominant position. Although the Nation-State came to dominate other state structures, this does not speak to the model's long-term survivability. Economists speak of "low-level equilibrium traps", ${ }^{29}$ whereby a particular model comes to dominate because in its initial performance it is more efficient than its competitors. However, the fact that it outperforms its competitors does not mean that it is operating to achieve maximum marginal utility, merely that its marginal utility is greater than that of its competitors at the time

\footnotetext{
${ }^{28}$ Keith G. Lumsden, Economics (London, 1991), p. 1/8.

${ }^{29}$ Spruyt, p. 16.
} 
of its rise to a position of dominance.

In the end, it is clear that by 1648 , the Nation-State had come to dominate both models of governance and the international arena, for a variety of economic reasons. Individuals and societies, pursuing their rational interests, had selected the Nation-State model for its ability to provide greater marginal utility than its competitors. But while the Nation-State has dominated the international scene ever since, it is also clear that fundamental changes in the economy could lead to the erosion of the Nation-State. If the economic factors that gave rise to the Nation-State change, or if other models of governance begin to provide greater marginal utility, it is conceivable that new models of governance could emerge, or old models re-emerge. Similarly, innovative approaches to governance could reveal the existence of a low-level equilibrium trap, in which the Nation-State is found to be less effective than old or new competitors in the longer term.

\section{Chapter Two: The nation-state today}

For 350 years, the Nation-State has dominated international discourse, and defined international relations. At the Congress of Vienna in 1815, the Nation-States repaired the damage done by Napoleon's imperial ambitions. At the Conference of Berlin in 1882, they carved up Africa for their own benefit. In the wake of World War I they created the League of Nations, and followed it up with the United Nations in 1945. Throughout this period, the Nation-State remained the stable centre around which international politics revolved. In the last few years, however, large numbers of observers and theorists have begun to discern cracks in the facade of the Nation-State system. To be fair, there have always been a few who saw the Nation-State as a model in decline. But in the 1990s, these few have become many, and the sheer volume of claims against the Nation-State requires that more careful attention be paid to the case being made.

There are, perhaps, two distinct views on the decline of the Nation-State, which may at first appear diametrically opposed. One school holds that the Nation-State is being replaced by something larger, something grander. These newly proposed structures may be supranational, or even civilizational, but they share a common trait of uniting Nation-States within a single framework. The second school of thought describes a counter-trend to fragmentation, disintegration and organizational anarchy. Here the newly emerging structures are built on petty ethnic nationalisms, on local and subnational interests, and on the collapse of the Nation-State.

The supranational school of thought is argued in a number of influential works. In his 1996 book, The Clash of Civilizations and the Remaking of World Order, Samuel Huntington sees a world in which the interests of Nation-States are disappearing, to be replaced by the interests of vast civilizational cultures. In Huntington's view, the Nation-State dominated the global scene from 
about 1500 until the collapse of the Soviet Empire in the period from 1989 to 1991. Since that time, we have seen the emergence of new power blocs, defined more by cultural, religious and historic links than by politics. Huntington postulates nine great civilizations, each with its distinct sphere of influence and agenda. These nine civilizations are:

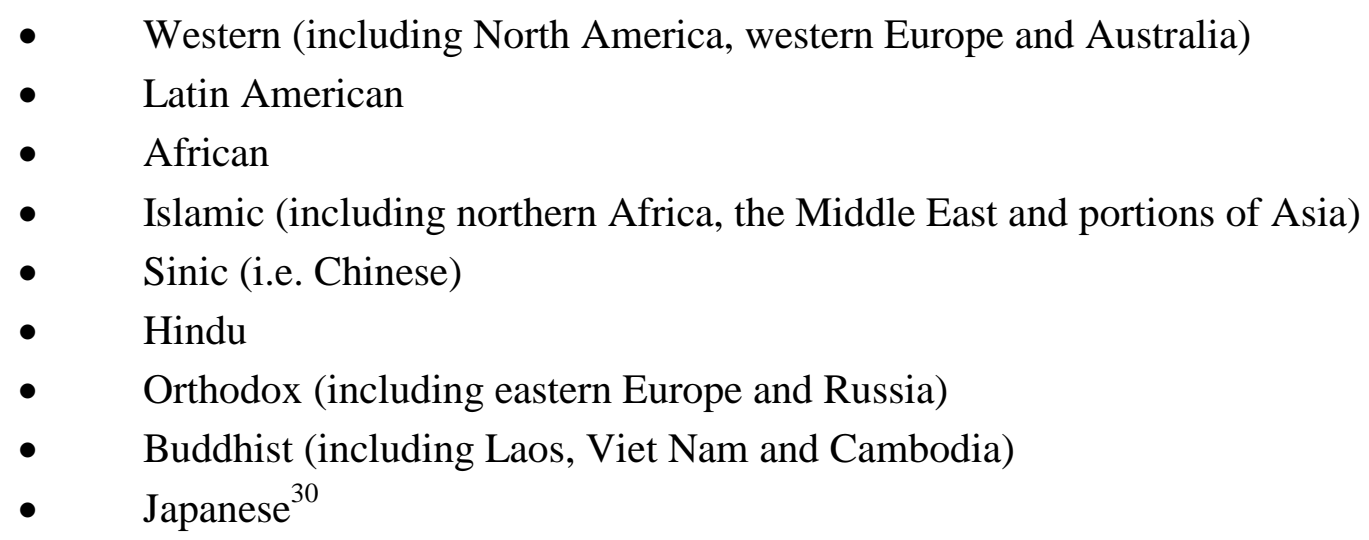

In Huntington's view, as clashes between civilizations increase, the importance of the NationState is likely to decline. Although far from universally accepted, Huntington's thesis has caused many to take note, and anecdotal evidence, including the surprising strength of Russian and Serbian Orthodox ties in the recent Kosovo conflict, has lent credence to his argument.

Richard Barnet and John Cavanagh have also proposed a new series of supranational players in their 1994 book Global Dreams: Imperial Corporations and the New World Order. In their view, "the balance of power in world politics has shifted in recent years from territorially bounded governments to companies that can roam the world." 31 Indeed, recent news reports regarding Microsoft Corporation, the U.S.-based software giant, underline that fact that in economic terms, some corporations may be more powerful than most governments. Microsoft, valued at more than US $\$ 500$ billion has a worth "32 per cent higher than the gross domestic product of the Netherlands, estimated at US\$378 billion. If Microsoft were a country, it would rank as the ninth-biggest economy in the world, behind Spain with a GDP of US\$553 billion."32

In his 1995 book Jihad Vs. McWorld, Benjamin Barber argues the emergence of McWorld, a "product of popular culture driven by expansionist commerce." ${ }^{33}$ A blend of Coca-Cola, MTV and materialist consumerism, McWorld undermines the traditional Nation-State through the creation of a single, commercially-driven global culture. "Hard power yields to soft," suggests Barber, "while ideology is transmuted to a kind of videology that works through sound bites and

\footnotetext{
${ }^{30}$ Samuel P. Huntington, The Clash of Civilizations and the Remaking of World Order (New York, 1996), pp. 26-27.

${ }^{31}$ Richard J.Barnet and John Cavanagh, Global Dreams: Imperial Corporations and the New World Order (New York, 1995), p. 14.

32 "Microsoft tops \$500-billion (U.S.) in market value," The Globe \& Mail, 17 July 1999, p. B3.

${ }^{33}$ Benjamin Barber, Jihad Vs. McWorld (New York, 1995), p. 17.
} 
film clips. Videology is fuzzier and less dogmatic than traditional political ideology...”34

Opposing this supranational process, and ironically gaining strength from it, is a counter-trend that Barber has described as Jihad. Divorcing the word from its overtly Islamic origins, Barber sees Jihad as "bloody war on behalf of partisan identity that is metaphysically defined and fanatically defended.... I use the term in its militant construction to suggest dogmatic and violent particularism of a kind known to Christians no less than Muslims, to Germans and Hindis as well as to Arabs.",35

Similar to Barber's bipolar argument, Dr. Bertrand Badie of l'Institut d'etudes politiques in Paris has proposed a tripolar model for explaining the declining influence of the Nation-State. In Badie's model, individuals are being pulled between three competing forces of citizenship, transnational entrepreneurialism and identitory entrepreneurialism. Citizenship's strength relies upon traditional notions of sovereignty and the Nation-State, and pulls people toward a loyalty to traditional national governments. Multinational entrepreneurs, who include both multinational corporations and international non-governmental organizations (NGOs), encourage people to develop more global and international perspectives and affiliations. Finally, identitory or identity-based entrepreneurs reflect Barber's Jihad, encouraging increased loyalty to "primordial" religious, linguistic or ethnic ties. ${ }^{36}$ In Badie's view, these three incompatible forces are in constant conflict, with the result that the ability of the Nation-State to govern without external compromise or interference is severely compromised.

Interestingly, despite their arguments about globalization, McWorld and multinational entrepreneurs, Badie, Barber and their ilk are forced to acknowledge the growing strength of subnational actors. Despite a trend to internationalization and globalization, most observers have been forced to admit that, to some extent, the international community is not coalescing but fragmenting. Indeed, despite the aggressive advance of McWorld's Big Macs and MTV, despite the rise of the European Union and the GATT, the international arena has increasingly been dominated by the fragmentary politics of Jihad and identitory association - often at the expense of the Nation-State.

In the February 1994 issue of The Atlantic Monthly, journalist Robert Kaplan published an article entitled 'The Coming Anarchy', in which he envisioned the collapse of the Nation-State. In the article and in his 1996 book The Ends of the Earth, Kaplan argued that rising ethnic and religious tensions, combined with environmental disaster, natural resource scarcity, refugee crises and rampant disease, will lead to the collapse of many Nation-States. In their place, an unstable

\footnotetext{
${ }^{34}$ Barber, p. 17.

${ }^{35}$ Barber, p. 9.

${ }^{36}$ Bertrand Badie, "To What Extent is Globalization Transforming What the State Can Do?", unpublished paper presented at Klingenthal, France,

21 June 1999.
} 
collection of warlords, tribal leaders and criminal gangs will rise to power. Innumerable small wars will erupt over oil and water and other scarce resources, until the line between warfare, ethnic tension and organized crime is completely blurred. "Future wars will be those of communal survival," suggests Kaplan:

These wars will be subnational, meaning that it will be hard for states and local governments to protect their own citizens physically. This is how many states will ultimately die. As state power fades - and with it the ability to help weaker groups within society, not to mention other states - peoples and cultures around the world will be thrown back upon their own strengths and weaknesses, with fewer equalizing methods to protect them. ${ }^{37}$

Kaplan's new world is already evident in the former Yugoslavia, in Rwanda, in the Congo, in Liberia, Sierra Leone, Chechnya, East Timor, Azerbaijan. In Kaplan's view the end of the Cold War has not so much heralded the triumph of democracy as it has the rebirth of history's most virulent and violent excesses. Nor is the process of national disintegration evident only in poorer regions of the world. A decade ago Scottish independence was at the fringes of British political life, while today it is a looming reality. Meanwhile, separatist movements thrive in Quebec, Northern Ireland, Basque and Catalonian Spain, Corsica, northern Italy and Belgium. Even in the richest, most stable Nation-States on earth, Kaplan's forces of disintegration are at work. Although Kaplan does not predict the same intensity of collapse for the West that may occur in Africa or Asia, he follows theorists like Joel Garreau (The Nine Nations of North America) and Darrell Delamaide (The New Superregions of Europe) in suggesting that future economic and political power will rest not with national governments, but with smaller regions of shared interests.

Although Kaplan's dramatic and far-reaching conclusions have inevitably spurred much debate, they have also attracted considerable academic support. As Morrison and Anderson ultimately conclude in Peacekeeping and the Coming Anarchy, "Alarmingly, conflicts throughout the world appear to be increasingly numerous, horrific and intractable. As Robert Kaplan has warned in his Atlantic Monthly article, 'The Coming Anarchy,' the tragic and frightening conditions which today exist in some parts of Western Africa serve as but a grim forecast of conditions which those in all parts of the world may ultimately face." 38

In the end, Kaplan's arguments represent the extreme results of Barber's Jihad or Badie's primordial, identitory forces. However, more restrained thinkers and academics, while not resorting to the somewhat alarmist arguments of Kaplan, are reaching the same conclusions.

\footnotetext{
${ }^{37}$ Robert Kaplan, “The Coming Anarchy,” Atlantic Monthly, February 1994, p. 74.

${ }^{38}$ Alex Morrison and Dale Anderson, eds., Peacekeeping and the Coming Anarchy (Cornwallis, 1996), p. 25.
} 
Robert Holton, in examining localized responses to external threats, has suggested that "Ethnicity offers higher levels of security against threat than do many other sources of identity and allegiance..." Jean-Marie Guehenno sees the "weakening of existing mediating institutions, public and private, and the direct confrontation of individuals with global forces... This evolution calls into question the role of political institutions: their power and relevance seem to recede..." ${ }^{40}$ And Tad Homer-Dixon, political scientist and presidential advisor, speaks for many when he suggests that Kaplan "has very vividly described a possible world that is now part of our range of thinking about where we might be thirty or forty years from now. It may be that only a portion of the world experiences that outcome - maybe nobody will experience it - but even if he's only 20 per cent right, that's bad enough." 41

Alongside these arguments about political collapse and increasing anarchy, a second group of thinkers has begun to argue the decline of the Nation-State from a technological perspective. In their 1997 book, The Sovereign Individual, James Dale Davidson and Lord William Rees-Mogg predict the end of the Nation-State as a direct result of the emerging Information Economy. Arguing that "Governments have already lost much of their power to regulate and compel" 42 the pair suggest that "megapolitical conditions in the West are undermining and destroying governments..."43

The crux of Davidson and Lord Rees-Mogg's argument revolves around taxation and the cybereconomy. Individuals and companies will increasingly be able to place their financial resources or liquid assets "in a cyberaccount in a cyberbank that is domiciled simultaneously in Newfoundland, the Cayman Islands, Uruguay, Argentina and Liechtenstein. If any of the jurisdictions attempt to withdraw operating authority or seize the assets of depositors, the assets will automatically be transferred to another jurisdiction at the speed of light.",44

In practical terms, this will ultimately mean that the ability of individual governments to control the flow of money - including control through taxation - will be eliminated. Without taxation, the traditional Nation-State collapses. As The Economist suggested in 1997, "In the coming decades electronic commerce - combined with the growing ease with which firms can shift their operations from one part of the world to another - will make it even easier for people to flee countries where taxes are too high, or to evade tax altogether by doing business in cyberspace." ${ }^{, 45}$

Famed management guru and social theorist Peter Drucker also sees the new information and knowledge-based economy undermining the Nation-State. "By definition," he argues, "a

\footnotetext{
${ }^{39}$ Robert J. Holton, Globalization and the Nation-State, (London, 1998), p. 150.

${ }^{40}$ Jean-Marie Guehenno, “The Impact of Globalization on Strategy,” Survival, 1998-99, p. 9.

${ }^{41}$ Mark Kingwell, "Meet Tad, the Doom-meister," Saturday Night, 1995, p. 44.

42 James Dale Davidson and Lord William Rees-Mogg, The Sovereign Individual (New York, 1997), p. 41.

${ }^{43}$ Davidson and Lord Rees-Mogg, p. 45.

${ }^{44}$ Davidson and Lord Rees-Mogg, p. 188.
} 
knowledge society is a society of mobility... mobility in terms of where one lives, mobility in terms of what one does, mobility in terms of one's affiliations. People no longer have roots." This mobility clearly decreases the importance of the traditional Nation-State structure. "Knowledge knows no boundaries. There is no domestic knowledge and no international knowledge. There is only knowledge. And with knowledge becoming the key resource, there is only a world economy...,

Nor is the question of mobility and its impact on the Nation-State related solely to the movement of individuals. As Epstein, Crotty and Kelly argue, the "increased mobility of foreign direct investment and multinational corporations is imposing real and increasingly severe constraints on... states." 48

Furthermore, the very notion of 'cyberspace' an extraterritorial locale beyond the control of Nation-States, may hasten the demise of formal Nation-State structures. Ryuhei Hosoya, a Senior Research Fellow at the Institute for International Policy Studies and a Japanese diplomat, has begun to explore the ramifications of this:

If cyberspace continues to develop beyond the control of governments, then national borders will for all practical purposes of society become meaningless, even though they may still exist in the physical world. If territoriality is an ultimate defining characteristic of the state, the state as a social concept is annulled. Thus, diplomacy will also cease to exist because it is, by definition, a function of the state. ${ }^{49}$

In the end, these varied and powerful arguments converge. Multinational forces and interests, including civilizations, transnational corporations and the banal commodification of McWorld all erode the power of the Nation-State to some degree. The rise of tribalistic affiliations, including those of ethnicity, religion and language, are diminishing Nation-States. Combined with increased social and environmental pressures, these tribal affiliations may lead to the collapse of the Nation-State. At the same time, the logical impact of many of the new information technologies is an erosion of the power and authority of the Nation-State. Beset from all sides, the Nation-State is showing increasing signs of frailty.

One obvious sign of this decline is the increasing fragmentation of Nation-States. Historically, new Nation-States have emerged only slowly, and existing Nation-States tended to maintain

\footnotetext{
45 “The Disappearing Taxpayer," The Economist, May $31^{\text {st }}-$ June $6^{\text {th }} 1997$, p. 15.

${ }^{46}$ Peter Drucker, "The Age of Social Transformation," Atlantic Monthly, November 1994, pp. 67-68.

${ }^{47}$ Drucker, "The Age of Social Transformation," p. 77.

${ }^{48}$ Gerald Epstein, James Crotty and Patricia Kelly, "Winners and Losers in the Global Economics Game," Current History, November 1996, p. 381.

${ }^{49}$ Ryuhei Hosoya, “Cyberspace and Virtual Diplomacy: the End of the Nation-State?”, International Institute for Policy Studies 1997, p. 4.
} 
territorial integrity. In recent decades, however, both of these trends have been reversed, with an exponential growth in the number of Nation-States.

\section{Figure 2.1. The creation and disappearance of nation-states, $1816-1973^{50}$}

$\begin{array}{lcc}\text { Time Period } & \text { States Created } & \text { States Disappearing } \\ 1816-1876 & 24 & 15 \\ 1876-1916 & 12 & 1 \\ 1916-1945 & 16 & 7 \\ 1945-1973 & 81 & 1\end{array}$

Since 1973, this process has accelerated. Indeed, the 1990s alone have seen the creation of more than twenty new Nation-States, as the Soviet Union (15 new Nation-States), Yugoslavia (5), Czechoslovakia (2) and Ethiopia (2) all fragmented. Other nations, from Indonesia to the United Kingdom, seem poised to follow. "The numbers tell the story," suggests Pascal Boniface. "In 1920, Europe had 23 states and 18,000 kilometres of frontiers; in 1994, it had 50 states, with 40,000 kilometres of borders. One wonders what the totals will be a decade hence."51

Nor is the rapid proliferation of smaller Nation-States the only sign that things are changing. The international arena is home to an increasing number of unrecognized states (Turkish Cyprus, Chechnya, Palestine) and failed states (Somalia, Sierra Leone). International diasporas (the Kurds, ethnic Albanians) are also becoming increasingly vocal participants in international issues. Supranational bodies (GATT, the European Union) are setting policy, while international NGOs (Amnesty International, Greenpeace) have an increasing say in decision-making. Multinational corporations (Shell Oil in Nigeria) are influencing government actions, while private armies (Congo, Liberia) are creating instability. Old nationalisms (Serbia, Russia) are once again becoming potent political forces, while religious fundamentalism (Islam, Sikhism) is increasingly influential on the international stage. Separatist movements (Quebec, Scotland, East Timor) are gaining strength. While there are still healthy Nation-States (the United States or Germany show no signs of breaking up, for example), they are increasingly rare. It is clear that some fundamental shift is underway, and the Nation-State model is suffering as a result.

The birth of the Nation-State was in large part due to a series of factors arising from the economic transformation of Europe in the period between 1000 and 1400, described in Chapter One. This economic renaissance was characterized by four fundamental changes:

1. a change in the perception of geography

\footnotetext{
${ }^{50}$ Adapted from Holton, p. 105. He was drawing upon earlier work by Thompson and Krasner.

${ }^{51}$ Pascal Boniface, "The Proliferation of States," Washington Quarterly, Summer 1998, p. 113.
} 
2. a change in the perception of time

3. a change in the use and form of money

4. a concentration of economic (and later political) power in the hands of a new economic class

These basic changes created a situation that promoted experimentation with new governance models, leading to the introduction and eventual dominance of the Nation-State.

Just as the economy underwent a basic shift in the Late Middle Ages, however, today's economy is being fundamentally changed by the advent of information technologies. And in a stunning parallel with the changes that gave rise to the Nation-State, the Information Economy involves a radical reinterpretation of geography, time and money. Further, the information revolution is also concentrating economic and political power in the hands of a new elite.

Contemporary notions of geography are being shaken by the new economy. Globalization has meant an end to regional isolation, and an increasing interconnectedness among spatially disparate communities. As Hosoya has described, the existence of a virtual cyberspace renders borders, and to some extent border controls, ineffective. ${ }^{52}$ As more and more business and interaction is conducted on-line, physical proximity becomes less important. Intriguingly, time takes on elements of geography, and time zones become the new continents as interaction is limited only by business hours and the necessity of sleep. Tools for distance communication and the transfer of information allow individuals separated by great distance to collaborate. The portability of information means that individuals are freer to move, between employers and between physical spaces. All of these changing perceptions of space and geography create a sense of a global marketplace, of a single global community without boundaries or borders. Ultimately, they create linkages and relationships to which the Nation-State, as a physical space, is an irrelevancy. In its entry for 'Globalization', the Encyclopedia of the New Economy puts it most succinctly: "Bye-bye borders." 53

Concepts of time are also being re-imagined in the Information Economy. If one studies the history of correspondence, this becomes clear; in 1815 it took months to exchange correspondence between London and New York. Indeed, the War of 1812 had been over for several weeks when the Battle of New Orleans was fought in January of 1815. Unfortunately, commanders in the field were not aware of the Treaty signed on 24 December of 1814. News of the Treaty did not reach Washington until 10 February. ${ }^{54}$ At the mid-point of the century, the advent of steamships shortened this communications lag-time from months to weeks, and by the 1920s, air travel had shortened the exchange to days. With the advent of same day courier service, fax machines and e-mail, the lag-time shrank from days to hours to minutes. The latest

\footnotetext{
${ }^{52}$ Hosoya, p. 3.

${ }^{53}$ John Browning and Spencer Reiss, “The Encyclopedia of the New Economy, Part II.”, Wired Magazine, April 1998, p. 95.

${ }^{54}$ Pierre Berton, Flames Across the Border (Markham, 1981), pp. 537-538.
} 
information tools, allowing the networking of technologies, mean that correspondence now takes place in real time. The longest it takes to communicate with any other location in the world over a networked system is $1 / 8$ th of a second. ${ }^{55}$ Not only has this change transformed business practice, with a new emphasis on just-in-time delivery and zero inventory practices, it has also created a work environment in which distance and borders are no longer a barrier to communication. In a sense, real-time communications eliminate borders, and make them irrelevant. Once again, the Nation-State begins to have less solidity and meaning because of the changes wrought by the Information Economy.

As in the Late Middle Ages, notions of money are also changing. First, the monopoly on production of money enjoyed by the Nation-State for several hundred years has begun to disappear. The European Union's European Currency Unit (ecu) is designed to replace national currencies, and to be beyond the control of any single national government. Similarly, many of the francophone countries of western Africa share a common currency. More fundamentally, however, information technology is giving rise to new forms of currency. Private companies offer e-cash, notional on-line currencies to facilitate virtual transactions. Furthermore, paper currency has in many cases been replaced by digital bits that represent currency - but which currency they actually represent can be changed with a keystroke. Similarly, a single keystroke can, in 1/8th of a second, deposit that digital currency in any location in the world. Not only does this new technology move money beyond the control of Nation-States, it actually places the ability to create currencies in structures other than Nation-States.

Finally, the Information Economy is creating immense wealth in a new sector of society. In the Late Middle Ages, the new wealth concentrated itself in the hands of the emerging merchant class, which saw great benefit in creating the political alliance that created the Nation-State. Today, immense wealth is being created amongst an 'information class', a group that combines knowledge with technical savvy. Whereas the merchant class was dedicated to a political system that assisted the organized flow of goods and capital, the information class envisions a world in which information is unrestricted. And since information is carried within the brains of individual people, this emerging group seeks an international system of governance that permits the free flow of people (or at least of educated, trained people). As Davidson and Lord ReesMogg suggest, this means that "Citizenship is obsolete."

Clearly, the economic conditions that prompted the rise of the Nation-State no longer exist. Notions of geography, time and money that were created in the economic renaissance of the Late Middle Ages are being transformed by the Information Economy. Furthermore, these changes are concentrating wealth and power in the hands of a new economic elite that may not see the

\footnotetext{
${ }_{55}^{55}$ Kevin Kelly, New Rules for the New Economy (New York, 1998), p. 94.

${ }^{56}$ Davidson and Lord Rees-Mogg, p. 373.
} 
Nation-State, with its rigid boundaries and systems of citizenship, as a governance structure suited to their interests. However, the economic realities of the Late Middle Ages only facilitated the creation of the Nation-State as an experimental form. It was its superior performance, its marginal utility, that led to the success of the form. As outlined in Chapter One, a select series of five special traits enabled the Nation-State to operate more effectively than competing systems of governance. These included:

1. The ability to standardize weights, measurements and currency within a larger geographic region

2. The ability to restrict free-riding within territorial boundaries

3. The ability to act independently of other political structures within the limits of sovereign territory

4. The ability to operate a clear, centralized and hierarchical decision-making structure

5. The ability of Nation-States as a 'Club of Nations' to determine who is or is not a legitimate player in the international arena.

If the economic factors that led to the creation of the Nation-State are no longer in place, and have in fact been replaced by economic approaches that devalue the Nation-State, can these operational advantages of Nation-States still exist?

In the Late Middle Ages, the ability of Nation-States to standardize weights, measures and currency within their own borders provided a built-in competitive advantage over other forms of governance. Globalization, however, has ended national standards, and replaced them in many instances with international standards. The vast majority of nations, for example, now operate on Napoleon's metric system, which does not rely on the Nation-State for its legitimacy. Currency is now a commodity, openly traded on international markets, with values set by the collective will of investors and speculators, rather than by individual governments. Even overtly national structures like postal services are governed by international bodies like the Universal Postal Union. Indeed, as the globalized Information Economy grows, it is becoming clear that NationStates can no longer provide the level of standardization desired by the international marketplace - so the market is inventing its own standards, like ISO 9000 and ISO 14000. "With a relentlessness that is astonishing even hardcore globalists," suggests the Encyclopedia of the New Economy, "worldwide markets and standards are rapidly emerging in finance, marketing, communications and transportation." 57 Not only is the Nation-State no longer the guarantor of

\footnotetext{
${ }^{57}$ Browning and Reiss, p. 95.
} 
standards, it is not the source of standards.

The second advantage of the Nation-State that emerged in the Late Middle Ages was its ability to restrict free-riding within its territory. As the $21^{\text {st }}$ Century begins, however, new forms of freeriding have been perfected. In particular, environmental degradation has become the free-ride activity of the day. As the ozone layer thins and the greenhouse effect warms the planet, individual responsibility has been abandoned in favour of collective burden, and Nation-States are seemingly powerless to change the pattern. Unable to act effectively as individual units to stop the free-riding, they have surrendered a degree of sovereignty to international structures like the United Nations, through agreements like the Montreal Protocol on ozone depletion, and the Kyoto Accord on greenhouse gases. Ironically, these UN-backed efforts are hampered by the free-riding activities of the Nation-States themselves - only about $10 \%$ of UN member states actually pay their membership dues to the organization. Further, these new UN-backed agreements often rely upon the private sector to develop mechanisms to end free-riding, as with the emissions trading schemes that lie at the heart of the Kyoto Accord. Ultimately, the ability to restrict free-riding has shifted upwards to international organizations, and downwards to individual private sector actors, leaving the Nation-State without significant power.

The third advantage of the Nation-State during its rise to dominance was its ability to act independently to make decisions within its sovereign territory. Where City-Leagues had to consult multiple stakeholders, for example, and feudal obligations brought conflicting perspectives to the table, the Nation-State functioned quickly and efficiently, and without outside interference. Such independence is no longer the case. International agreements and bodies like the United Nations restrict some kinds of activity. Multinational corporations influence the economic and trade policies of nations. Ethnic, religious and nationalistic movements force concessions and special rights from governments. And increasingly, non-governmental organizations play a key role in both policy development and implementation. As Jessica Matthews of the influential Council on Foreign Relations argues, "At a time of accelerating change, NGOs are quicker than governments to respond to new demands and new opportunities. Internationally, in both the poorest and richest countries, NGOs, when adequately funded, can outperform government in the delivery of many public services." 58 Again, the one-time advantage of the Nation-State structure appears to have disappeared.

The fourth structural advantage of the Nation-State over competing models of governance was its hierarchical structure. A linear, streamlined decision-making process proved effective for making and enforcing decisions, and for ensuring long-term political stability. Under this hierarchical model, Hosoya suggests, the traditional Nation-State model sees "actors at different levels focus primarily on vertical communication channels in the domestic hierarchy, while

\footnotetext{
${ }^{58}$ Jessica Matthews, "Power Shift," Foreign Affairs, January-February 1997, p. 63.
} 
coordinating at the international level, but only with their own counterparts." ${ }^{, 59}$ This model is represented graphically (Figure 2.2).

This model was the norm for Nation-States and their citizens for many centuries. Authority flowed from the Nation-State down to actors within its territory. These actors could interact with each other within the Nation-State, but their external actions and obligations were limited. The Boy Scouts, for example, might link with Boy Scouts in other countries, but not with foreign corporations or foreign governments.

The hierarchical model is increasingly being replaced, however, by other more interactive models. Hosoya has termed this emerging model 'Network-type Interaction', and has suggested that this new model represents "a more complex web of interaction" representing "an ever more diversified mix of interests." ${ }^{\circ 0}$ This model can also be represented graphically (Figure 2.3).

\section{Figure 2.2. Hierarchical interaction ${ }^{61}$}

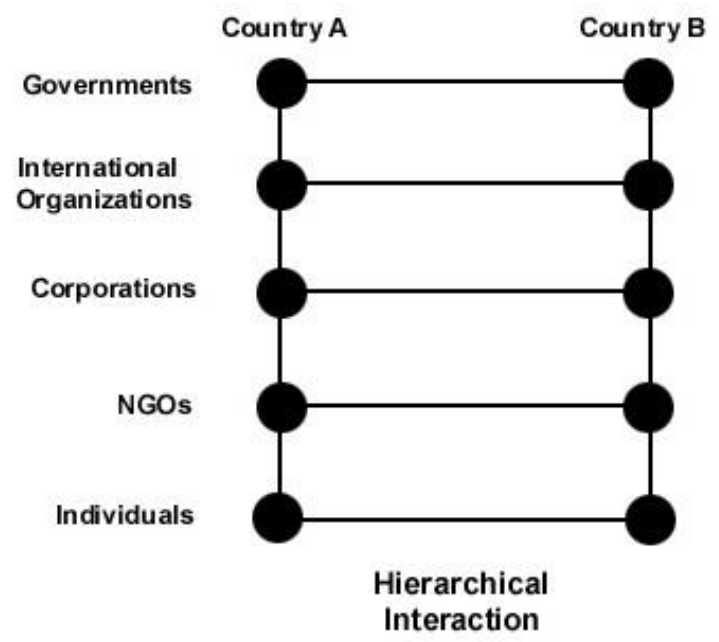

Under this model, authority is not only a vertical phenomenon, as in classically hierarchical structures, but a horizontal phenomenon. Actors not only develop relationships within the domestic context, but also at the international level. Thus, Greenpeace may be based in Country A, but will interact directly with Country B. Indeed, it may then attempt to influence a private sector corporation in Country $\mathrm{C}$, and carry out a fundraising campaign in Country D. As the number of actors swells, so does the web of possible interactions.

Clearly, this emerging model directly conflicts with the ability of Nation-States to function as

\footnotetext{
${ }^{59}$ Hosoya, p. 10.

${ }^{60}$ Hosoya, p. 10 .

${ }^{61}$ Adapted from Hosoya, p. 10.
} 
hierarchical models. Indeed, the new 'networked' decision-making structures increasingly resemble the feudal models that the Nation-State replaced. Spruyt recounts the example of John Toul, a noble with feudal obligations to four separate lords: Lord John of Arcis, Lord Enguerran of Coucy, the Count of Champagne, and the Count of Grandpre. As Toul himself explained his situation:

Figure 2.3. Network-type interaction ${ }^{62}$

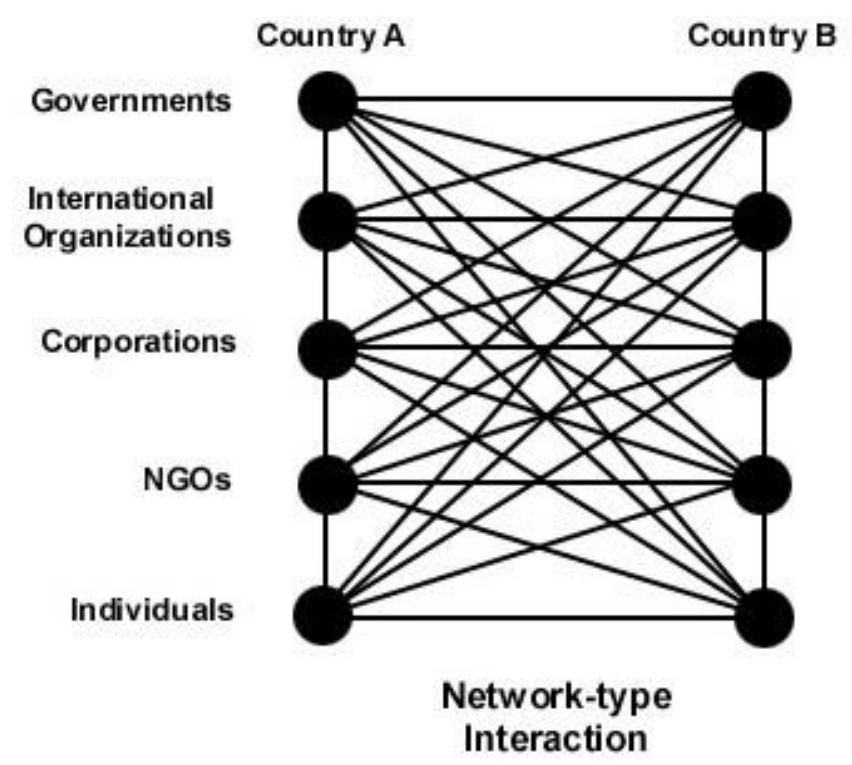

If it should happen that the Count of Grandpre should be at war with the Countess and Count of Champagne for his own personal grievances, I will personally go to the assistance of the Count of Grandpre and will send to the Countess and Count of Champagne, if they summon me, the knights I owe for the fief [land grant] which I hold of them. But if the Count of Grandpre shall make war on the Countess and Count of Champagne on behalf of his friends and not for his own personal grievances, I shall serve in person with the Countess and Count of Champagne and I will send one knight to the Count of Grandpre to give the service owed from the fief which I hold of him. But I will not myself invade the territory of the Count of Grandpre." 63

At least in part, this too can be depicted graphically as in Figure 2.4.

Clearly, this confusing feudal model (which has not fully outlined Toul's obligations to Arcis and

\footnotetext{
${ }^{62}$ Adapted from Hosoya, p. 10.
} 
Coucy) more closely resembles Hosoya's networked model than the traditional hierarchical model of the Nation-State. The growing use of this networked model is thus indicative of a trend away from the hierarchical approach that made the Nation-State so effective.

\section{Figure 2.4. Feudal Interaction}

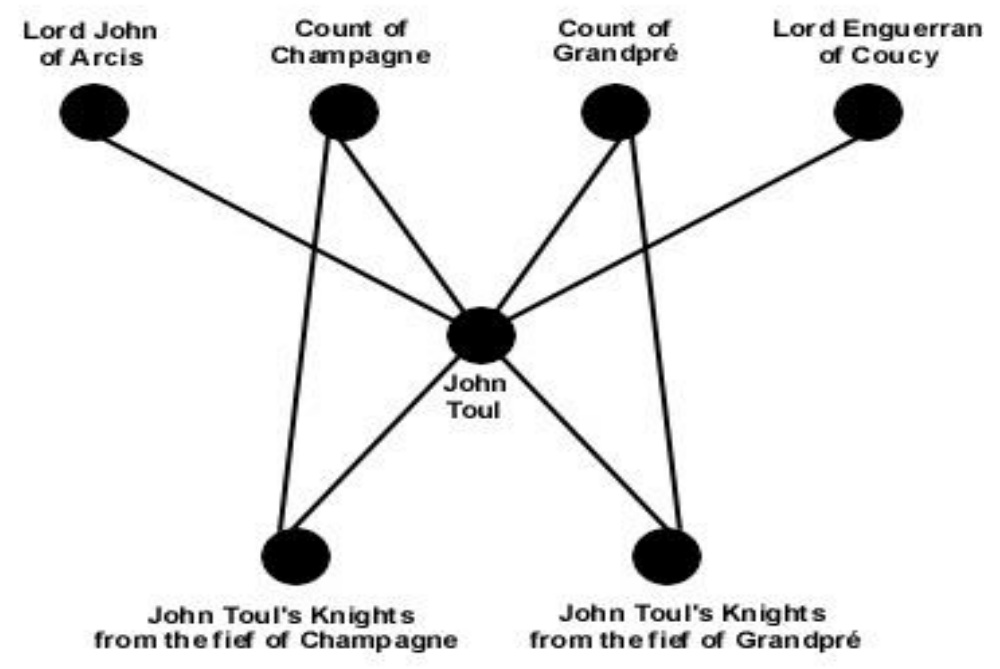

Even in many so-called dictatorial societies, the hierarchical structure of the Nation-State is being tempered by an increasingly feudalistic exchange of obligations. Patrick Chabal and Jean-Pascal Daloz have recently described an African political model based on the instrumentalization of disorder and the traditional African concept of the patrimonial 'big man' or authority figure. ${ }^{64}$ However, as among the Germanic tribes that gave rise to feudalism, the legitimacy of this 'big man' figure is based almost solely upon his ability to provide benefits to his followers and kin group. Thus, despite the relative failure of governance structures, "it is clear that in many African countries (like Cote d'Ivoire, Mozambique, Senegal, or Guineau Bissau) ruling parties were returned to power in part simply because they were perceived to be more able to deliver on expected patrimonial promises than their competitors. $" 65$

With quasi-feudal notions influencing African governments (and perhaps others), and widespread models of networked interaction that more closely resemble feudal systems than traditional Nation-State interactions, it seems clear that the international community is moving away from strictly hierarchical relationships. This change suggests that the traditional means of organizing

\footnotetext{
${ }^{63}$ Spruyt, p. 39.

${ }^{64}$ Patrick Chabal and Jean-Pascal Daloz, Africa Works: Disorder as Political Instrument (Bloomington, 1999), p. 155-162.

${ }^{65}$ Chabal and Daloz, p. 158.
} 
Nation-States, and a long-term source of the Nation-State's structural advantage over competing governance structures, is becoming increasingly irrelevant.

The final advantage of the Nation-State structure is its ability to legitimize and empower other Nation-States. In legal and judicial circles, this is known as the comity of nations, an "archaic and notoriously vague term beloved by diplomats and international lawyers" that "signified the deference one nation grants another in recognition of their mutual sovereignty." 66 Under this concept, Nation-States, while supreme within their own territory, are equal to each other at the international level. Moreover, this equality is based upon mutual recognition and deference; in other words, if Nation-States do not recognize a state, if they don't extend the comity of nations, that state cannot become a full-fledged Nation-State.

From the earliest days of Nation-States, this exclusionary principle has been a powerful tool. The Nation-States of Europe deliberately excluded the Hanseatic League from participating in the Peace of Westphalia in 1648, a blow that hastened the League's demise. Similarly, the League of Nations was, and the United Nations is, based upon the comity of nations and the exclusion of participants and actors that member states do not wish to recognize. In the beginning, this ability allowed Nation-States to exert greater political control over the international arena. As time has passed, however, this exclusionary approach has created pockets of wilderness on the political landscape. Having recognized Somalia, Nation-States are in a quandary as to how to proceed now that the country has no government. The case of Taiwan is also problematic. About twenty nations recognize the island republic, but out of deference to China, most do not. Is that enough to make it a real Nation-State? Perhaps most importantly, the repeated withholding of recognition from a series of increasingly independent territories reflects the Nation-State's inability to cope with changing political realities. Bruce Sterling has written of the (unrecognized) Turkish Republic of Northern Cyprus as a "living, breathing futurist scenario for a new sort of planetary area..." ${ }^{\circ 7}$ He suggests that Turkish Cypriots:

live outside the New World Order's game plan. As do plenty of others: a brief roll includes Kosovo, Bosnia, the Bekaa Valley, Chechnya, Nagorno-Karabakh, Abkhazia, East Timor, northern Iraq, southern Iraq, every bit of Afghanistan, the Sudan, Algeria, Kashmir, South Lebanon, the Western Sahara, and the Gaza Strip. ${ }^{68}$

The reluctance to recognize some of these states is understandable. Recognition of Chechnya, for example, would bring conflict with Russia. Increasingly, however, these cases of nonrecognition reveal the inability of the Nation-State model to cope with ongoing processes of

\footnotetext{
${ }^{66}$ Anne-Marie Slaughter, "The Real New World Order," Foreign Affairs, September-October 1997, p. 190.

${ }^{67}$ Bruce Sterling, “One Nation, Invisible," Wired Magazine, August 1999, p. 92.

${ }^{68}$ Sterling, p. 92.
} 
international change. Ignoring the situation in Kosovo or the Gaza Strip is not an effective strategy; sooner or later, the blinkers come off and the international community gets drawn into conflict. Indeed, the comity of nations makes such conflict inevitable. If only Nation-States can participate in the United Nations, and Palestine or Kosovo are not Nation-States, they have no clear place within the international arena. As a result, there is no clear way to address their conflicts and concerns. Many of these regions ultimately become rogue states; Turkish Cyprus and Chechnya, for example, are hotbeds of international organized crime. Unless Nation-States establish comity with such rogue states, they will be unable to address the serious problems that arise out of their shadowy status. Thus, while Nation-States have jealously guarded and retained the ability to recognize each other, to grant comity, this power is not always a benefit to the Nation-State structure. Indeed, it runs the risk of increasing the challenges faced by the NationState in many situations.

Clearly, the world is changing around the Nation-State. The economic factors that brought about experimentation with the Nation-State form in the Late Middle Ages have changed again with the advent of the Information Economy. As concepts of time, geography and money change, it seems logical to assume that structures built on the old notions will be affected. Similarly, the strengths and abilities that made the Nation-State the dominant model of governance are also being called into question by changes in the international order. These changes strike at the heart of the Nation-State's utility. In a sense, the Nation-State rose to dominance because it offered the greatest marginal utility, the greatest difference between the costs and benefits of participation, of all the models of governance available. But obviously, both the costs and benefits of the NationState structure are changing. In the 15th and 16th Centuries, the Nation-State offered great utility, greater than that of all competing forms. This may not be the case in the 21 st and 22nd Centuries. As Jessica Matthews puts it:

In the Middle Ages, emperors, kings, dukes, knights, popes, archbishops, guilds and cities exercised overlapping secular power over the same territory in a system that looks much more like a modern, three-dimensional network than the cleanlined, hierarchical... [Nation-State] that replaced it. The question now is whether there are new geographic or functional entities that might grow up alongside the state, taking over some of its powers and emotional resonance. ${ }^{69}$

If the marginal utility of the Nation-State is declining - and the evidence seems to suggest that it is - then it is inevitable that political entrepreneurs will begin to experiment with alternative structures. Short of some form of global government, the Nation-State is unlikely to ever disappear completely. Many strong Nation-States remain in the world, and old forms, like the Knights of Malta or the City-State of San Marino, have a way of hanging on. Still, it seems

\footnotetext{
${ }^{69}$ Matthews, p. 61.
} 
likely that in the future a variety of governance structures will exist side by side, as they have in the past. This will undoubtedly create a much more complicated international system, but it may also create a more effective one. Indeed, the great challenge for policy-makers will not be in finding ways to prop up failing states. The real task that we face today is to anticipate the changes that are taking place, and find a way to fashion an international order that takes advantage of the strengths of the emerging models, that capitalizes on their marginal utility. And in this period of change, great political and economic opportunity may exist for those regions and communities that are best prepared.

\section{Chapter Three: Policy implications}

The fundamental economic and political changes shaking the Nation-State model require radical and far-reaching policy responses. At international, national and subnational levels, it is clear that traditional policy tools and approaches must give way, to be replaced by a range of new and often disconcertingly unfamiliar strategies. However, for those who are able to adapt to these new models, and make them work, significant opportunity for increasing political power and rapid economic development exist. Conversely, for those who do not adapt, the dangers of irrelevance and economic stagnation loom large.

At the international level, significant actors including the United Nations must begin to look outside the comity of nations, in order to involve emerging non-Nation-State actors in significant and influential roles. To a certain extent, this process has already begun. Since 1948, the United Nations Economic and Social Council (ECOSOC) has allowed NGOs an opportunity to liaise directly with governments on policy development and decision-making. In 1948, however, ECOSOC had only 41 members. By 1998, ECOSOC had more than 1500 NGO members. ${ }^{70}$ Clearly, the UN structure has been relatively forward looking in its approach to NGOs. On the other hand, membership in the General Assembly and in other official structures, for example, the 54-member governing council of the United Nations Environment Programme (UNEP), has been strictly limited to Nation-States by the principles of comity. Although observer status has occasionally been granted to groups like the African National Congress (ANC) or the Palestine Liberation Organization (PLO), most unrecognized but independent or quasi-independent states have no voice at the UN. From Taiwan to Turkish Cyprus, effectively autonomous states have been excluded from the international arena. Similarly, stateless peoples have little or no voice. The Kurds, for example, who lie at the centre of one of the world's geopolitical hotspots, have no say in international discussions about their region. Ultimately, these deficiencies will weaken the United Nations and other international structures. To avoid this fate, international bodies - and the so-called international community that enforces the comity of nations - must expand their perspectives and their memberships to allow 'ghost' states and stateless peoples a voice.

\footnotetext{
${ }^{70}$ P.J. Simmons, "Learning to Live With NGOs," Foreign Policy, Fall 1998, p. 83.
} 
Once this international community has been broadened to include all participants, it must work to address a fundamental problem caused by the decline of the Nation-State. In the past, an important role of the Nation-State was the prevention of free-riding. As the Nation-State declines in power, international bodies must increasingly adopt this role. In particular, international structures will be necessary to oppose environmental free-riding, where individuals and corporations benefit at the cost of generalized suffering and ecosystem collapse. As the impacts of such free-riding become global in nature - ozone depletion, deforestation, desertification, global warming - so too must the measures to combat them.

The free-ride dilemma also lies at the heart of a second necessary international policy direction. As knowledge comes to drive the Information Economy, intellectual property will become a key economic and strategic asset. As Charles Mann desribes it:

Today, it is widely believed that personal computers, cable television, the Internet, and the telephone system are converging into a giant hose that will spray huge amounts of data - intellectual property - into... living rooms. As this occurs... the economic winners will be those who own the zeros and ones [binary-coded data], not those who make the equipment that copies, transmits and displays them. Because copyright is the mechanism for establishing ownership, it is increasingly seen as the key to wealth in the Information Age. ${ }^{71}$

Free-riders will increasingly attempt to use the intellectual property of others for their own benefit, a practice that will undermine economic and political stability. To combat this tendency, the international community must adopt stringent and broad-based intellectual property rights. This underlines the need to incorporate unrecognized states into the international system. Taiwan, for example, has long been a free-rider in intellectual property terms. Future effort to address this problem will depend upon both the willingness of the international community to act, and the degree of inclusion of non-Nation-State actors like Taiwan.

Finally, as the ability of Nation-States to enforce national tax regimes declines, some on the left are suggesting that the international community should consider a move toward some form of international agreement on taxation. This too is a response to free-riding, as the inability of Nation-States to control mobile capital leads to an erosion of social structures. As Kapstein has argued:

It may be objected that countries should have the right to impose zero tax rates on mobile capital if they wish, and that tax policy lies squarely within the domestic

\footnotetext{
${ }^{71}$ Charles C. Mann, “Who Will Own Your Next Good Idea?”, Atlantic Monthly, September 1998, p. 58.
} 
purview. The problem here is that tax policies have spillover effects on other countries and on the global economy as a whole. In essence, these states are cheating on the system, just like countries with lax pollution codes. To the extent that social safety nets contribute to global political and economic stability, every economic agent, no matter where located, should contribute to them. ${ }^{72}$

Voices on the right of the political spectrum oppose an international tax agreement, decrying artificial restrictions on the free flow of capital. Indeed, Davidson and Lord Rees Mogg have enthused about the "great transformation that is destined to reduce the grip of political authorities upon the cash flow..."73 Destiny aside, it seems clear that the international community will at least have to grapple with issue of capital mobility. While capital in the Information Age may prove to be beyond the reach of governments, it also seems unlikely that this discussion will occur without some attempt by the international community to develop a policy approach restricting such capital mobility.

National policy responses to the decline of the Nation-State will no doubt prove particularly interesting. As their sovereign authority declines, and competing models of governance emerge alongside them, many Nation-States will no doubt fight a rearguard action to retain their legitimacy. It seems likely that some will be successful in this endeavour. There are several policy approaches that may prove beneficial in such cases.

First, Nation-States must strengthen their linkages with NGOs. Increasingly, NGOs have become an avenue for some Nation-States to exert their policy values and directions on the world stage. The close links between Canada and the NGO community in realizing both the International Criminal Court and the international ban on landmines demonstrate the efficacy of this approach. ${ }^{74}$ Obviously, such links can only be made where interests overlap, but shrewd NationStates will seek out NGOs that share a common perspective. Indeed, in some instances they may actually create such NGOs - the term GONGO, or Government-Organized Non-Governmental Organization, has recently entered international parlance. In addition to their policy support role, NGOs may also play a strong role in policy implementation. At the meetings to establish the International Criminal Court, legal advice for both Sierra Leone and Bosnia was provided by the NGO No Peace Without Justice. NGOs with a focus on international development are increasingly being sub-contracted to carry out the work of national foreign aid agencies, including CIDA in Canada, and USAID in the United States. As the international prestige and influence of such NGOs grows, Nation-States must link more closely with them to increase the effectiveness of their own programs, and defend their national interests in the international arena.

\footnotetext{
${ }_{72}^{72}$ Ethan B. Kapstein, “A Global Third Way: Social Justice and the World Economy,” World Policy Journal, Winter 1998-99, p. 33.

${ }_{73}^{73}$ Davidson and Lord Rees-Mogg, p. 282.

${ }^{74}$ Simmons, p. 91.
} 
A second major policy change for Nation-States is necessary in the arena of security.

Traditionally, Nation-States have focused their military strategies on the relative strengths and weaknesses of other, adversarial Nation-States. But as Nation-States decline in power, and other structures arise, security threats will increasingly come from non-Nation-State sources. Additionally, such threats will not take the traditional high-intensity form of massive armies confronting each other on a battlefield, but will appear as low-intensity confrontations. As military theorist Martin Van Creveld puts it, "Either modern states cope with low-intensity conflict, or else they will disappear..."75 Thus concepts of military security or national security are replaced with concerns about environmental security, food security and economic security. In the latter case, for example, the security of the Nation-State may ultimately have more to do with how well it competes in the Information Economy, and how well it protects its competitive advantages, than it has to do with tanks and bombers.

The advent of the globalized economy provides another policy direction for Nation-States: embrace the global system, or be left behind. Nation-States are, by definition, territorial, and external threats to sovereign power are often met with isolationist responses. Kennedy has argued that beginning in the 1960s, "many Latin American [and Caribbean] governments pursued a policy of import substitution, creating their own steel, cement, paper, automobiles, and electronics goods industries, which were given protective tariffs, government subsidies, and tax breaks to insulate them from international competition. As a result, their products became less attractive abroad." In contrast, he suggests that the Asian economies set out to "create a strong base from which to mount an export offensive - not to establish an economic bastion within which their industries would be content to remain."76 As a review of some Latin American and Caribbean economic growth statistics show, the substitution approach did not work.

Figure 3.1. Per capita GDP in US\$ for selected Latin American and Caribbean nations ${ }^{77}$

$\begin{array}{lrrrr}\text { Country } & \mathbf{1 9 6 0} & \mathbf{1 9 7 0} & \mathbf{1 9 8 0} & \mathbf{1 9 8 8} \\ & & & & \\ \text { Argentina } & 2,384 & 3,075 & 3,359 & 2,862 \\ \text { Bolivia } & 634 & 818 & 983 & 724 \\ \text { El Salvador } & 832 & 1,032 & 1,125 & 995 \\ \text { Guyana } & 1,008 & 1,111 & 1,215 & 995 \\ \text { Haiti } & 33 & 292 & 386 & 319 \\ \text { Jamaica } & 1,610 & 2,364 & 1,880 & 1,843 \\ \text { Nicaragua } & 1,055 & 1,495 & 1,147 & 819 \\ \text { Peru } & 1,233 & 1,554 & 1,716 & 1,503\end{array}$

\footnotetext{
${ }^{75}$ Martin Van Creveld, The Transformation of War (New York, 1991), p. 224.

${ }^{76}$ Paul Kennedy, Preparing for the Twenty-First Century (New York, 1993), pp. 203-204.

${ }^{77}$ Adapted from Kennedy, p. 203.
} 
In spite of the recent 'Asian Flu', signalling a downturn in Asian economies, the success of the Asian 'tiger' economies stands in sharp contrast to the thirty-year stagnation in much of Latin America and the Caribbean. Indeed, many Asian economies have demonstrated sustained periods of high economic growth. ${ }^{78}$ In the future, it seems likely that failure to be a full participant in the global economy will signal the end of many weakening Nation-State structures. Those who can maintain a strong and viable link to the international economy, however, may have opportunities for survival.

John Gallup and Jeffrey Sachs have gathered empirical data of another economic policy direction that may be helpful to Nation-States in the future. As their power declines, and as many NationStates begin to fragment and break up, great care must be taken by Nation-States redrawing their borders. Gallup and Sachs have empirically demonstrated that landlocked Nation-States significantly underperform Nation-States with ocean access in economic terms. Outside of Europe, landlocked countries have an average GDP of US\$1,683 while coastal countries have an average GDP of US\$5,555. ${ }^{79}$ In the division of Nation-States like the Soviet Union, the former Yugoslavia and Ethiopia, this principle was apparently not taken into account. In the future, such considerations will be more important. From an economic development perspective:

Coastal regions, and regions linked to coasts by ocean-navigable waterways, are strongly favoured in development relative to the hinterlands. Landlocked countries in particular may find themselves at an extreme disadvantage, even when they are no farther than the interior parts of coastal economies. Three reasons seem to figure prominently to explain the phenomenon. First, crossborder migration of labour is more difficult than internal migration. Second, infrastructure development across national borders is much more difficult to arrange than similar investments within a country. Lastly, coastal economies may have military or economic incentives to impose costs on interior landlocked economies. $^{80}$

From this point of view, the war between Ethiopia and Eritrea takes on additional geopolitical and economic significance. Without adequate policy preparation and strategic planning, other Nation-States may find themselves in a similar situation. By far the most sweeping strategies for dealing with the massive changes in the international political arena will need to be developed at the subnational or local level. While international structures like the United Nations and national governments are caught up in the processes of change, communities will be forced to cope with

\footnotetext{
${ }^{78}$ Kennedy, p. 201.

${ }^{79}$ John Gallup and Jeffrey Sachs, "Location, Location: Geography and Economic Development," Harvard International Review, Winter 1998-99, p. 57.

${ }^{80}$ Gallup and Sachs, p. 58.
} 
the results of change. It is clear that while this poses grave threats to political stability and social cohesion, it also offers significant opportunity for those communities who are best able to adapt to the emerging global reality.

First and foremost, local communities must strive to understand and reflect the realities of the Information Economy. Communities must seek greater levels of connectedness, and embrace decision-making and planning by network. As hierarchical systems fade in efficiency, networked structures will rise in importance. In essence, this means wider participation in decision-making processes. Hierarchies are, by nature, exclusive in approach, while networks "are nurtured by making it as easy as possible to participate." ${ }^{\prime 1}$ Ideally, such networks will operate in real time. As information theorist Kevin Kelly puts it, "If you are not in real time, you're dead." 82

Second, communities must realize that the only true engine of economic growth in the Information Economy is knowledge. Peter Drucker suggests that how well a community does in "acquiring and applying knowledge will become the key competitive factor. The knowledge society will be far more competitive than any society we have yet known - for the simple reason that with knowledge being universally accessible, there will be no excuses for non-performance. There will be no 'poor' countries. There will only be ignorant countries." 83

To ensure their competitive edge, communities will thus be increasingly called upon to retain and recruit - the brightest minds, and to emphasize education, training and capacity-building to ensure continued growth of knowledge and innovation. Examples of the failure to follow such a policy are abound. Tanzania suffers as one of the poorest countries in Africa, in part because it had only 120 university graduates at the time of independence. ${ }^{84}$ Mauritius, sometimes described as 'Africa's only tiger economy', has fallen into economic stagnation, in part because "more than a third of Mauritian children still fail to graduate from primary school, and secondary school completion rates are well below 50 per cent." 85

The importance of a solid knowledge base, arising from quality educational initiatives is clear. Paul Kennedy has gone so far as to suggest that every study of American competitiveness has stressed the same issue: to compete, the United States must "vastly improve the level of skill and training among the work force at large and provide opportunities for thorough retraining; and raise educational standards..."86 Communities must embrace such messages, and adopt such approaches. Only by ensuring adequate local supplies of knowledge and ingenuity will they be able to compete in the international marketplace. Furthermore, such localized expertise may

\footnotetext{
${ }^{81}$ Kelly, New Rules for the New Economy, p. 79.

${ }^{82}$ Kelly, New Rules for the New Economy, p. 21.

${ }^{83}$ Drucker, "The Age of Social Transformation," pp. 67-68.

${ }^{84}$ P.J. O'Rourke, Eat the Rich: A Treatise on Economics (New York, 1998), p. 197.

${ }^{85}$ Deborah Brautigam, "Mauritius: Rethinking the Miracle," Current History, May 1999, p. 228.

${ }^{86}$ Kennedy, pp. 337-338.
} 
allow them to participate in the Information Economy regardless of what events transpire in the larger Nation-State.

Thirdly, communities should not tie themselves too closely to the Nation-State. Economic independence can never be a bad thing. Inside a strong Nation-State, it is a prestigious local advantage. Should the Nation-State become increasingly ineffective or collapse altogether, it becomes an absolute necessity. In considering such matters, communities may even begin to experiment with their own forms of alternative governance. If the Nation-State no longer provides a competitive advantage, some communities may opt for a new system, just as Singapore opted to become a City-State in the 1960s. Indeed, Gallup and Sachs suggest some empirical evidence to indicate that some communities should abandon the Nation-State model. In 1995, the only two tropical states among the top 30 Nations-States (ranked by GDP) were Hong Kong and Singapore - both City-States. ${ }^{87}$ This may indicate that in some geographic situations, models other than the Nation-State are most conducive to a community's economic growth. In other words, models other than the Nation-State may offer the greatest marginal utility to participants.

Finally, communities should endeavour to engage NGOs directly. Ideally, communities will be able to entice NGOs to locate within their region. As described above, NGOs can offer advantageous international linkages, they often prove effective at policy implementation, and they increase a community's knowledge base. Perhaps most importantly, however, NGOs provide outstanding opportunities for employment and economic growth. NGOs in the broadly defined field of 'relief', for example, spend more than US\$8 billion a year. Indeed, some analysts speak of 'The Big Eight', a group of NGOs each controlling more than a half a billion dollars annually. ${ }^{88}$ Such resources represent significant economic opportunity for communities, and while every community cannot attract one of the Big Eight, every community can attract NGOs.

In the end communities must undertake the same analysis practiced by the citizens of the Late Middle Ages. For a time, the Nation-State provided its citizens with a distinct economic advantage; the Nation-State offered greater utility than its competitors. As a result, it rose to international dominance. It has defined and directed international relations since the Peace of Westphalia in 1648. Today, however, communities are being forced to re-examine the costs and benefits of living and doing business within the Nation-State. In some instances, the NationState remains a strong and powerful structure for governance. But in an ever-growing number of situations, the Nation-State's efficacy is being called into question.

\footnotetext{
${ }^{87}$ Gallup and Sachs, p. 57.

${ }^{88}$ The eight are CARE, World Vision International, Oxfam Federation, Medecins Sans Frontieres, Save the Children Federation, Eurostep, CIDSE

(Cooperation internationale pour le developpement et la solidarite) and APDOVE (Association of Protestant Development Organizations in

Europe). Simmons, p. 92.
} 
This is not, of course, a strictly economic question. But the birth of the Nation-State is best explained in economic terms, and the future of the Nation-State rests, at least in part, on its ability to meet economic needs and expectations. Such huge transformations and macrohistoric trends, of course, take centuries to play themselves out. Indeed, the Nation-State required centuries for its own birth. The decline of the Nation-State will also be a lengthy process of fits and starts. Ultimately, however, the process of change will have its way, and nations, regions and communities that anticipate this change will be better positioned to pursue tomorrow's economic opportunities.

\section{Acknowledgements}

Many individuals have provided advice, assistance and insight during the preparation of this paper. Without their expertise, the final product would have been much poorer. Political and diplomatic insight came from Marc Ablong, Assistant Director of National Supports Mobilisation Concepts at Australian Defence Headquarters; Ambassador Rafael A. Alfaro, El Salvador's representative to Israel; Andre Bachand, MP, foreign affairs critic for the Progressive Conservative Party of Canada; Ambassador Lakhdar Brahimi, Special Representative of the United Nations Secretary-General; Robert Cooper, Director for the Asia-Pacific region at the British Foreign and Commonwealth Office; Kadri Kallikorm of the External Economic Policy Department at the Ministry of Foreign Affairs in Estonia; Irakli Kurashvili, First Secretary of the Western European Department at the Ministry of Foreign Affairs in Georgia; Geoff Mulgan, of the Prime Minister's Policy Unit at Number 10 Downing Street; and Chima Nweze, High Court Judge in Enugu State, Nigeria.

Academic insights came from a variety of sources, but the following were especially generous with their time and information: Bertrand Badie, with the Political Science Department at l'Institut d'etudes politiques, Paris; Patrick Chabal, of the Department of African Studies at King's College, University of London; Gunther Dietz, of the Anthropology Department at the University of Granada, Spain; and David Sinclair, with the Constitution Unit at University College London.

Others who provided invaluable assistance included Father John Patrick Ngoyi, Director of the Justice, Development and Peace Commission in Nigeria; Eric Nonacs of Co-operation Ireland; and Zoran Kusovac, Balkans correspondent for Jane's Defence Weekly and Jane's Intelligence Review. Special thanks to Sir Michael Weir, whose $21^{\text {st }}$ Century Trust placed me in direct contact with many of the people listed above, and to Emanuel Carvalho with the Department of Economics at the University of Waterloo, for supervising my work on this paper.

Any errors that remain are, of course, my own. 


\section{Author's biography}

Brock Dickinson is the Executive Director of the Western Valley Development Authority in Nova Scotia, an agency the United Nations Centre for Human Settlements called one of the one hundred Best Practices in the world for improving living conditions. Promoted as a model of economic development by UNESCO and the World Bank, his work has helped transform one of Atlantic Canada's poorest regions into a thriving, independent community linked to the global marketplace. A widely published author and popular public speaker, Dickinson spent six years as a consultant with the United Nations, advising governments on five continents about development issues. In addition to his Nova Scotia work, he continues to do consulting work for government and agencies around the world. Dickinson teaches economic development at Saint Mary's University in Canada and the University of Novosibirsk in Russia, and is a Fellow of the United Kingdom's $21^{\text {st }}$ Century Trust.

\section{Bibliography}

Badie, Bertrand, "To What Extent is Globalization Transforming What the State Can Do?", unpublished paper presented at Klingenthal, France, 21 June 1999.

Barber, Benjamin R., Jihad VS. McWorld. Ballantine Books, New York, 1995.

Barnet, Richard J. and John Cavanagh, Global Dreams: Imperial Corporations and the New World Order, Simon \& Schuster, New York, 1995.

Berton, Pierre, Flames Across the Border, Penguin Books, Markham, 1981.

Boniface, Pascal, “The Proliferation of States," Washington Quarterly, Washington, Summer 1998, pp. 111-127.

Brautigam, Deborah, "Mauritius: Rethinking the Miracle," Current History, Philadelphia, May 1999, pp. 228-231.

Browning, John and Spencer Reiss, “The Encyclopedia of the New Economy, Part II," Wired Magazine, San Francisco, April 1998, pp. 92-102.

Chabal, Patrick \& Jean-Pascal Daloz, Africa Works: Disorder as Political Instrument, Indiana University Press, Bloomington, 1999.

Cohen, Robin, "Diasporas and the Nation-State: From Victims to Challengers," International 
Affairs, July 1996, 14 unnumbered pages.

Cooper, Robert, "The Historical Development of the Nation-State and Some Questions About Its Future," unpublished paper circulated by the 21st Century Trust, London, 1999.

Davidson, James Dale and Lord William Rees-Mogg, The Sovereign Individual, Simon \& Schuster, New York, 1997.

Delamaide, Darrell, The New Superregions of Europe, Plume Books, New York, 1994.

“The Disappearing Taxpayer,” The Economist, London, May 31st- June 6th, 1997, pp 15, 21-23.

Drezner, Daniel, “Globalizers of the World, Unite!", Washington Quarterly, Washington, Winter 1998, pp.209-225.

Drucker, Peter, “The Age of Social Transformation," Atlantic Monthly, New York, November 1994, pp. 53-80.

Drucker, Peter, "The Global Economy and the Nation-State," Foreign Affairs, January-February 1997, pp. 159-171.

Epstein, Gerald, James Crotty and Patricia Kelly, "Winners and Losers in the Global Economics Game," Current History, Boston, November 1996, pp. 377-381.

Gallup, John and Jeffrey Sachs, "Location, Location: Geography and Economic Development," Harvard International Review, Boston, Winter 1998-99, pp. 56-61.

Garreau, Joel, The Nine Nations of North America. Houghton Mifflin Company, Boston, 1981.

Guehenno, Jean-Marie, “The Impact of Globalisation on Strategy,” Survival, Winter 1998-99, pp. 5-19.

Holton, Robert J., Globalization and the Nation State, MacMillan, London, 1998.

Homer-Dixon, Tad, "Environmental Scarcity, Mass Violence and the Limits to Ingenuity," Current History, Boston, November 1996, pp. 359-365.

Hosoya, Ryuhei, “Cyberspace and Virtual Diplomacy: The End of the Nation-State?”, Institute for International Policy Studies 1997, pp. 1-18. 
Howarth, Stephen, The Knights Templar, Barnes and Noble Books, New York, 1982.

Huntington, Samuel P., The Clash of Civilizations and the Remaking of World Order, Simon \& Schuster, New York, 1996.

Kaplan, Robert, “The Coming Anarchy,” Atlantic Monthly, Boston, February 1994, pp. 44-76.

Kaplan, Robert, The Ends of the Earth, Random House, New York, 1996.

Kapstein, Ethan B., "A Global Third Way: Social Justice and the World Economy,” World Policy Journal, New York, Winter 1998-99, pp. 23-33.

Kelly, Kevin, New Rules for the New Economy. Viking Penguin, New York, 1998.

Kelly, Kevin, "Wealth is Overrated and Other Heresies, as Pronounced by Peter Drucker," Wired Magazine, San Francisco, March 1998, pp. 160-161.

Kennedy, Paul, Preparing for the Twenty-First Century, Random House, New York, 1993. Kingwell, Mark, "Meet Tad, the Doom-meister," Saturday Night, Toronto, September 1995, pp.42-49.

Klare, Michael T., "Redefining Security: The New Global Schisms," Current History, Philadelphia, November 1996, pp. 353-358.

Landes, David S., The Wealth and Poverty of Nations, W.W. Norton \& Company, New York, 1998.

Lipsey, Richard G., Economic Growth, Technological Change and Canadian Economic Policy, C.D. Howe Institute, Vancouver, 1996.

Lumsden, Keith G., Economics, Pitman Publishing, London, 1991.

Mann, Charles C., "Who Will Own Your Next Good Idea?", Atlantic Monthly, Boston, September 1998, pp. 57-82.

Matthews, Jessica, “Power Shift,” Foreign Affairs, January-February 1997, pp. 50-66.

Mehmet, Ozay, "The Poverty of Nations: The Eurocentric Bias of Development Economics," Harvard International Review, Boston, Winter 1998-99, pp. 52-55. 
"Microsoft tops \$500-billion (U.S.) in market value," The Globe \& Mail, Toronto, 17 July 1999, p. B3.

Morici, Peter, "Managing the Global Economy's Managers," Current History, Philadelphia, November 1998, pp. 374-379.

Morrison, Alex and Dale Anderson, eds., Peacekeeping and the Coming Anarchy, Canadian Peacekeeping Press, Cornwallis, 1996.

O'Rourke, P.J., Eat The Rich: A Treatise on Economics, Atlantic Monthly Press, New York, 1998.

Ottaway, Marina, "Post-Imperial Africa at War," Current History, Philadelphia, May 1999, pp. 202-207.

Painter, Sidney, The Rise of the Feudal Monarchies, Cornell University Press, Ithaca, 1951.

Pope, William Henry, All You Must Know About Economics (Second Edition), Bergendal, Uxbridge, 1997.

Post, Gaines, Sovereignty and its Limitations in the Middle Ages (1150-1350), Nauka Publishing House, Moscow, 1970.

Rotberg, Robert I., "The Leadership Factor: The Political Dimensions of Africa's Economic Development," Harvard International Review, Boston, Winter 1998-99, pp. 72-75.

Schraeder, Peter J., “Japan's Quest for Influence in Africa," Current History, Philadelphia, May 1999, pp. 232-234.

Shearer, David, “Outsourcing War,” Foreign Policy, Washington, Fall 1998, pp. 68-81.

Simmons, P.J. ,"Learning to Live With NGOs,” Foreign Policy, Washington, Fall 1998, pp. 8296.

Simon, Edith, The Piebald Standard: The Story of the Knights Templars, White Lion Publishers, Aldershot, 1959.

Slaughter, Anne-Marie, “The Real New World Order,” Foreign Affairs, September-October 1997, pp. 183-197. 
Speth, James Gustave, “A New Deal: Development Assistance in a Global Economy,” Harvard International Review, Boston, Winter 1998-99, pp. 48-51.

Spruyt, Hendrik, The Sovereign State and Its Competitors, Princeton University Press, Princeton, 1994.

Sterling, Bruce, “One Nation, Invisible," Wired Magazine, San Francisco, August 1999, pp. $92-$ 108.

Van Creveld, Martin, The Transformation of War, Simon \& Schuster, New York, 1991.

Wade, Robert, "The Asian Crisis and the Global Economy: Causes, Consequences, and Cure," Current History, Philadelphia, November 1998, pp. 361-373. 